\title{
Rat neuronal nicotinic acetylcholine receptors containing a7 subunit: pharmacological properties of ligand binding and function
}

\author{
Yingxian XIAO ${ }^{1, *}$, Galya R ABDRAKHMANOVA ${ }^{2}$, Maryna BAYDYUK ${ }^{1}$, Susan HERNANDEZ ${ }^{1}$, Kenneth J KELLAR ${ }^{1}$ \\ ${ }^{1}$ Department of Pharmacology, Georgetown University School of Medicine, Washington, DC 20057, USA; ${ }^{2}$ Department of Pharmacology and Toxicology, \\ Virginia Commonwealth University, Richmond, VA 23298, USA
}

\begin{abstract}
Aim: To compare pharmacological properties of heterologously expressed homomeric a7 nicotinic acetylcholine receptors ( $\alpha 7 \mathrm{nAChRs)}$ with those of native $\mathrm{nAChRs}$ containing $\alpha 7$ subunit ( ${ }^{*} 7^{*} \mathrm{nAChRs}$ ) in rat hippocampus and cerebral cortex. Methods: We established a stably transfected HEK-293 cell line that expresses homomeric rat a7 nAChRs. We studies ligand binding profiles and functional properties of $n A C h R s$ expressed in this cell line and native rat $a 7^{*} n A C h R s$ in rat hippocampus and cerebral cortex. We used $\left[{ }^{125} \mathrm{I}\right]$ - $\alpha$-bungarotoxin to compare ligand binding profiles in these cells with those in rat hippocampus and cerebral cortex. The functional properties of the a7 $\mathrm{nAChRs}$ expressed in this cell line were studied using whole-cell current recording.

Results: The newly established cell line, KXa7R1, expresses homomeric a7 nAChRs that bind [ $\left.{ }^{125} \mathrm{I}\right]$-a-bungarotoxin with a $K_{d}$ value of $0.38 \pm 0.06 \mathrm{nmol} / \mathrm{L}$, similar to $K_{d}$ values of native rat $a 7^{*} \mathrm{nAChRs}$ from hippocampus $\left(K_{d}=0.28 \pm 0.03 \mathrm{nmol} / \mathrm{L}\right)$ and cerebral cortex $\left(K_{d}=0.33 \pm 0.05 \mathrm{nmol} / \mathrm{L}\right)$. Using whole-cell current recording, the homomeric a7 nAChRs expressed in the cells were activated by acetylcholine and (-)-nicotine with $\mathrm{EC}_{50}$ values of $280 \pm 19 \mu \mathrm{mol} / \mathrm{L}$ and $180 \pm 40 \mu \mathrm{mol} / \mathrm{L}$, respectively. The acetylcholine activated currents were potently blocked by two selective antagonists of a7 nAChRs, a-bungarotoxin $\left(\mathrm{IC}_{50}=19 \pm 2 \mathrm{nmol} / \mathrm{L}\right)$ and methyllycaconitine $\left(\mathrm{IC}_{50}=100 \pm 10 \mathrm{pmol} / \mathrm{L}\right)$. A comparative study of ligand binding profiles, using 13 nicotinic ligands, showed many similarities between the homomeric a7 nAChRs and native $\alpha 7^{*}$ receptors in rat brain, but it also revealed several notable differences.

Conclusion: This newly established stable cell line should be very useful for studying the properties of homomeric a7 $\mathrm{nAChRs}$ and comparing these properties to native $\alpha 7^{*} \mathrm{nAChRs}$.
\end{abstract}

Keywords: neurotransmitter release; memory; Alzheimer's disease

Acta Pharmacologica Sinica (2009) 30: 842-850; doi: 10.1038/aps.2009.69; published online 18 May 2009

\section{Introduction}

Neuronal nicotinic acetylcholine receptors containing $\alpha 7$ subunits $\left(\alpha 7^{*} \mathrm{nAChRs}\right)$ are widely expressed in the CNS, and have been studied extensively ${ }^{[2-8]}$. When expressed in Xenopus oocytes ${ }^{[9,10]}$ or mammalian cells ${ }^{[11]}$, these receptors are highly permeable to calcium ion ${ }^{[12-14]}$. The $\alpha 7$ nAChRs have been implicated in a wide range of physiological functions, including neurotransmitter release ${ }^{[15,16]}$, activation of second messengers, apoptosis and neuroprotection ${ }^{[17,18]}$. More recent evidence indicates that $\alpha 7 \mathrm{nAChRs}$ may be

* Correspondence to Yingxian XIAO.

E-mail yxiao02@georgetown.edu

A preliminary report of this work has been presented at 2003 Society for Neuroscience Annual Meeting ${ }^{[1]}$.

Received 2009-03-04 Accepted 2009-04-20 directly involved in learning and memory ${ }^{[19,20]}$, pathology of Alzheimer's disease ${ }^{[21-23]}$, and inflammation ${ }^{[24]}$. The advance in our understanding of the biological properties and roles of $\alpha 7^{*}$ nAChRs has suggested new therapeutic strategies and drug candidates targeting $\alpha 7 \mathrm{nAChRs}$ for treatment of CNS disorders, including Alzheimer's disease ${ }^{[25,26]}$.

Stably transfected mammalian cell lines heterologously expressing neuronal $\mathrm{nAChR}$ subtypes have been powerful tools to study neuronal nAChRs ${ }^{[11,27-32]}$. Several such cell lines expressing functional $\alpha 7 \mathrm{nAChRs}$ were successfully established in recent years, including the rat $\alpha 7$ subunit gene expressed in SH-SY5Y human neuroblastoma cells, which also express endogenous nAChR $\alpha 3, \alpha 5, \alpha 7, \beta 2$, and $\beta 4$ subunit genes ${ }^{[33]}$; the human $\alpha 7$ subunit gene expressed in HEK-293 cells $^{[11]}$ and in SH-EP1 clonal human epithelial cells $^{[34,35]}$, both of which are devoid of endogenous nAChR 
subunits; and the rat $\alpha 7$ subunit gene expressed in $\mathrm{GH}_{4} \mathrm{C}_{1}$ clonal rat pituitary cells, which endogenously express the rat nAChR $\beta 4$ subunit gene ${ }^{[36,37]}$.

In the present study, we established a stable clonal mammalian cell line that expresses the rat $\alpha 7$ gene and functional $\alpha 7$ receptors that mediate rapidly desensitizing currents in response to acetylcholine and nicotine. The pharmacological properties of the ligand binding site of these recombinant rat $\mathrm{nAChRs}$ were compared to those in native rat $\alpha 7^{*} \mathrm{nAChRs}$ from hippocampus and cerebral cortex.

\section{Materials and methods}

Materials and chemicals Tissue culture medium, fetal bovine serum, antibiotics, restriction endonucleases, modifying enzymes and molecular size standards were obtained from Invitrogen Corp (Carlsbad, CA). $\left[{ }^{125} \mathrm{I}\right]-\alpha$-Bungarotoxin ([ $\left.\left[{ }^{125} \mathrm{I}\right]-\alpha-\mathrm{BTX}, 180-260 \mathrm{Ci} / \mathrm{mmol}\right),\left[\alpha-{ }^{32} \mathrm{P}\right] \mathrm{CTP}(800$ $\mathrm{Ci} / \mathrm{mmol})$ and $\left[\gamma^{-32} \mathrm{P}\right]$ ATP $(3000 \mathrm{Ci} / \mathrm{mmol})$ were obtained from Amersham Biosciences Corporation (Piscataway, NJ). Electrophoresis reagents were purchased from Bio-Rad Laboratories (Melville, NY). All other chemicals were purchased from Sigma Chemical Co (St Louis, MO), unless otherwise stated. Rat brain tissues were dissected from brains purchased from Zivic-Miller Laboratories (Zelienople, PA).

Cell culture and stable transfection HEK-293 cells (ATCC CRL 1573) were maintained at $37^{\circ} \mathrm{C}$ with $5 \% \mathrm{CO}_{2}$ in a humidified incubator. Growth medium for the HEK293 cells was minimum essential medium supplemented with $10 \%$ fetal bovine serum, $100 \mathrm{U} / \mathrm{mL}$ penicillin $\mathrm{G}$, and $100 \mu \mathrm{g} / \mathrm{mL}$ streptomycin. A eukaryotic expression construct was made using the full-length cDNA of the rat $\alpha 7$ subunit gene (a generous gift from Dr James W PATRICK of Baylor College of Medicine). Transfection of HEK-293 cells, and selection and establishment of stable cell lines were carried out as described previously ${ }^{[27]}$, with minor modifications. Briefly, transfections were carried out using Lipofectamine 2000 transfection reagent (Invitrogen Corp). From each transfected population of cells, 48 stable, G418 resistant cell clones were isolated after cultivation in selective medium for 4 weeks. These clonal cell lines were then grown in selection medium for an additional 4 weeks.

Total RNA Isolation and RNase protection assay Total cellular RNA was isolated from tissues using RNASTAT- $60^{\mathrm{TM}}$, a RNA isolation reagent (TEL-TEST “B”, Inc, Friendswood, TX). DNA templates for antisense riboprobes were prepared as described previously ${ }^{[27]}$. The size of the full length probes and the expected protected fragments of the probes are as following: rat $\alpha 2,416$ and 332 bases; rat $\alpha 3,306$ and 230 bases; rat $\alpha 4,496$ and 408 bases; rat $\alpha 5$, 411 and 380 bases; rat $\alpha 6,462$ and 396 bases; rat $\alpha 7,450$ and 376 bases; rat $\beta 2,322$ and 263 bases; rat $\beta 3,430$ and 394 bases; rat $\beta 4,252$ and 170 bases; rat glyceraldehyde-3phosphate-dehydrogenase (GAPDH), 204 and 135 bases; human GAPDH, 220 and 130, respectively. The probes were synthesized using T7 RNA polymerase (Ambion, Austin, TX) and $\left[\alpha-{ }^{32} \mathrm{P}\right]$ CTP. Specific activities of $\left[\alpha-{ }^{32} \mathrm{P}\right]$ CTP used for synthesizing the probes of rat $\mathrm{nAChR}$ subunit genes and the probe of GAPDH were $800 \mathrm{Ci} / \mathrm{mmol}$ and $32 \mathrm{Ci} / \mathrm{mmol}$, respectively. Approximately $20 \mu \mathrm{g}$ total RNA was hybridized with probes overnight at $42{ }^{\circ} \mathrm{C}$. Nonprotected probes were digested with a mixture of RNase A and RNase T1, and the samples were processed using RPA II kit (Ambion, Austin, TX). Protected fragments were separated by electrophoresis on a $6 \%$ denaturing polyacrylamide gel. Positions and densities of the fragments were visualized and analyzed by X-ray filming or phosphor imaging.

Membrane homogenate preparation and $\left[{ }^{125} I\right]-\alpha-B T X$ binding assay Membrane homogenates for ligand binding assays were made as described previously ${ }^{[27]}$ with minor modifications. Briefly, cultured cells at $>90 \%$ confluency were removed from the culture flask $\left(80 \mathrm{~cm}^{2}\right)$ with a disposable cell scraper and placed in $10 \mathrm{~mL}$ of $50 \mathrm{mmol} / \mathrm{L}$ Tris. $\mathrm{HCl}$ buffer $\left(\mathrm{pH} 7.4,4^{\circ} \mathrm{C}\right)$. The cell suspension was centrifuged at $1000 \times g$ for $5 \mathrm{~min}$ and the pellet was collected. The cell pellet was then homogenized in $10 \mathrm{~mL}$ buffer with a polytron homogenizer for $20 \mathrm{~s}$ and centrifuged at $35000 \times \mathrm{g}$ for $10 \mathrm{~min}$ at $4{ }^{\circ} \mathrm{C}$. Rat brain tissues ( $500 \mathrm{mg}$ tissue in $10 \mathrm{~mL}$ buffer) were homogenized and centrifuged similarly. Membrane pellets were resuspended in fresh buffer.

$\left[{ }^{125} \mathrm{I}\right]$ - $\alpha$-BTX solutions were made in $50 \mathrm{mmol} / \mathrm{L}$ Tris. $\mathrm{HCl}$ buffer containing $0.8 \mathrm{mg} / \mathrm{mL}$ bovine serum albumin (BSA, Sigma A-7030). Aliquots of the membrane homogenates containing 30 to $200 \mu \mathrm{g}$ protein were used for the binding assays, which were carried out in a final volume of $100 \mu \mathrm{L}$ in borosilicate glass tubes. After incubation at $24^{\circ} \mathrm{C}$ for $4 \mathrm{~h}$, the samples were collected with a cell harvester (Brandel M-48) onto Whatman GF/C filter papers pre-wet with $0.5 \%$ polyethylenimine (PEI). Before harvesting the samples, about $3 \mathrm{~mL}$ of $50 \mathrm{mmol} / \mathrm{L}$ Tris $\mathrm{HCl}$ buffer containing $0.5 \mathrm{mg} / \mathrm{mL}$ BSA and $0.5 \%$ PEI was sucked into the harvester and through the filter to reduce nonspecific binding of $\left[{ }^{125} \mathrm{I}\right]-\alpha-\mathrm{BTX}$ to plastic and glass surfaces. After harvesting the samples, the filters were washed three times with $5 \mathrm{~mL}$ of $50 \mathrm{mmol} / \mathrm{L}$ Tris $\mathrm{HCl}$ buffer, and then counted in a liquid scintillation counter. Nonspecific binding was measured in samples containing $1 \mathrm{mmol} / \mathrm{L}(-)$-nicotine incubated in parallel. Specific binding was defined as the difference between 
total binding and nonspecific binding. Data from saturation and competition binding assays were analyzed using Prism 4 (GraphPad Software, San Diego, CA).

Whole-cell current recording Functional expression of $\alpha 7 \mathrm{nAChRs}$ was evaluated in the whole-cell configuration of the patch-clamp technique using an Axopatch 200B amplifier (Molecular devices, Sunnyvale, CA). The patch electrodes, pulled from borosilicate glass capillaries (Sutter Instrument Company, Novato, CA), had a resistance of 2.5-3.5 $\mathrm{M} \Omega$ when filled with internal solution containing $110 \mathrm{mmol} / \mathrm{L}$ Tris phosphate dibasic, $28 \mathrm{mmol} / \mathrm{L}$ Tris base, $11 \mathrm{mmol} / \mathrm{L}$ EGTA, $2 \mathrm{mmol} / \mathrm{L} \mathrm{MgCl}_{2}, 0.1 \mathrm{mmol} / \mathrm{L} \mathrm{CaCl}_{2}$ and $4 \mathrm{mmol} / \mathrm{L} \mathrm{Na-ATP} \mathrm{(pH} \mathrm{adjusted} \mathrm{to} 7.3$ with Tris base). Stably transfected HEK-293 cells were studied 2 to $3 \mathrm{~d}$ after plating cells on the $15-\mathrm{mm}$ round plastic coverslips (Thermanox, Nalge Nunc, Napierville, IL). Generation of voltageclamp protocols and acquisition of the data were carried out using pCLAMP 9.0 software (Molecular Devices). Sampling frequency was $10 \mathrm{kHz}$ and current signals were filtered at 5 $\mathrm{kHz}$ before digitization and storage. All experiments were performed at room temperature $\left(22-25^{\circ} \mathrm{C}\right)$.

Cells plated on cover slips were transferred to an experimental chamber mounted on the stage of an inverted microscope (Olympus IX50, Olympus Corporation, Tokyo, Japan) and were bathed in a solution containing $140 \mathrm{mmol} / \mathrm{L} \mathrm{NaCl}$, $3 \mathrm{mmol} / \mathrm{L} \mathrm{KCl}, 2 \mathrm{mmol} / \mathrm{L} \mathrm{MgCl}_{2}, 25 \mathrm{mmol} / \mathrm{L} D$-glucose, 10 $\mathrm{mmol} / \mathrm{L}$ HEPES and $2 \mathrm{mmol} / \mathrm{L} \mathrm{CaCl}$ ( $\mathrm{pH}$ adjusted to 7.4 with Tris base). The experimental chamber was constantly perfused with control bathing solution (1-2 $\mathrm{mL} / \mathrm{min}$ ). The high-speed solution exchange system, HSSE-2 (ALA Scientific Instruments, Westbury, NY) was used to deliver agonist or antagonist to the cell. Under optimal conditions, the delay in switching between solutions is $\sim 10 \mathrm{~ms}$. 8 out of 12 patched cells responded to agonists $(8-30 \mathrm{pA} / \mathrm{pF}$ with $1 \mathrm{mmol} / \mathrm{L}$ acetylcholine at $-80 \mathrm{mV}, n>36$ ). In experiments aimed to determine the inhibitory potency of methyllycaconitine (MLA) or $\alpha$-BTX, the cell under recording was exposed initially to acetylcholine at its $\mathrm{EC}_{50}$ concentration. The cell was then exposed to the antagonist at the studied concentration for 2-8 $\mathrm{min}$ before a co-application of acetylcholine with the antagonist. Only one concentration of the antagonist was tested on each cell, and a new coverslip with cells was used each time.

The peak amplitude of the whole-cell currents was determined using the pCLAMP 9.0 program, the leak current was subtracted. $\mathrm{EC}_{50}, \mathrm{IC}_{50}$, and the $n \mathrm{H}$ values were evaluated with the Origin 5.0 program (Microcal, North Hampton, $\mathrm{MA})$. To determine $\mathrm{EC}_{50}$ values, acetylcholine-or nicotineinduced responses were recorded at $-80 \mathrm{mV}$ and normalized to the amplitude of the current elicited by acetylcholine alone at its saturating concentration $(1 \mathrm{mmol} / \mathrm{L})$. Values were plotted against the concentration of acetylcholine on a logarithm scale and fitted with an equation: $I=I_{\max } /$ $\left(1+\left(\mathrm{EC}_{50} /[\text { agonist }]\right)^{n \mathrm{H}}\right)$, where $I$ is the current amplitude at the agonist concentration [agonist], $I_{\max }$ is the maximum current, $\mathrm{EC}_{50}$ is the concentration of the agonist eliciting a half maximum response and $n \mathrm{H}$ is the Hill coefficient. The acetylcholine (about $\mathrm{EC}_{50}$ )-evoked currents in the presence of MLA or $\alpha-B T X$ were measured at $-80 \mathrm{mV}$ and normalized to the amplitude of the current elicited by acetylcholine alone. Values were plotted against the concentrations of the inhibitor on a logarithm scale and fitted with an equation: $I=I_{\max } /$ $\left(1+\left(\mathrm{IC}_{50} /[\text { antagonist }]\right)^{n \mathrm{H}}\right)$, where $I$ is the current amplitude at the antagonist concentration [antagonist], $I_{\max }$ is the maximum current, and $n \mathrm{H}$ is the Hill coefficient. Results are presented as the mean \pm SEM for the number of cells $(n)$.

\section{Results}

Stable transfection of HEK-293 cells From each population of transfected cells, 48 stable, G418-resistant cell clones were isolated after cultivation in selection medium for 4 weeks. These clonal cell lines were then grown in selection medium. Initial screenings of the G418-resistant clonal cells were carried out by measuring mRNA and by $\left[{ }^{125} \mathrm{I}\right]-\alpha-\mathrm{BTX}$ ligand binding assays. Among all cell lines examined, the clonal cell line that showed the highest expression level of the rat $\alpha 7 \mathrm{nAChR}$ subunit gene was used in all of the following studies. This cell line was designated KX $\alpha 7 \mathrm{R} 1$.

Analyses of a 7 subunit mRNA of the KXa7R1 cells Multiplex RNase protection assays were carried out to measure mRNAs coded by rat neuronal $\mathrm{nAChR}$ subunit genes, including $\alpha 2, \alpha 3, \alpha 4, \alpha 5, \alpha 6, \alpha 7, \beta 2, \beta 3$, and $\beta 4$. Total RNA was isolated from each of the clonal cell lines as well as from the HEK-293 parent cells. As expected, the only nAChR subunit mRNA transcript detected in the KXa7R1 cells was the one coding for $\alpha 7 \mathrm{mRNA}$ (Figure 1).

Specific binding of $\left[{ }^{125} I\right]-a-B T X$ to membrane preparations The expression of the $\alpha 7$ nicotinic receptors in KXa7R1 cells was analyzed by measuring the binding of $2 \mathrm{nmol} / \mathrm{L}\left[{ }^{125} \mathrm{I}\right]-\alpha-\mathrm{BTX}$. Untransfected parental HEK293 cells showed no specific binding of $\left[{ }^{125} \mathrm{I}\right]-\alpha$-BTX (Figure 2); whereas the KXa7R1 cells showed high specific binding(about $75000 \mathrm{DPM} / \mathrm{mg}$ protein), which represented $>70 \%$ of the total binding. We also examined the binding of $2 \mathrm{nmol} / \mathrm{L}\left[{ }^{125} \mathrm{I}\right]-\alpha-B T X$ to membranes from several established cell lines that express combinations of an $\alpha$ and a $\beta$ subunits, including combinations of $\alpha 2 \beta 2, \alpha 2 \beta 4, \alpha 3 \beta 2, \alpha 3 \beta 4$, 


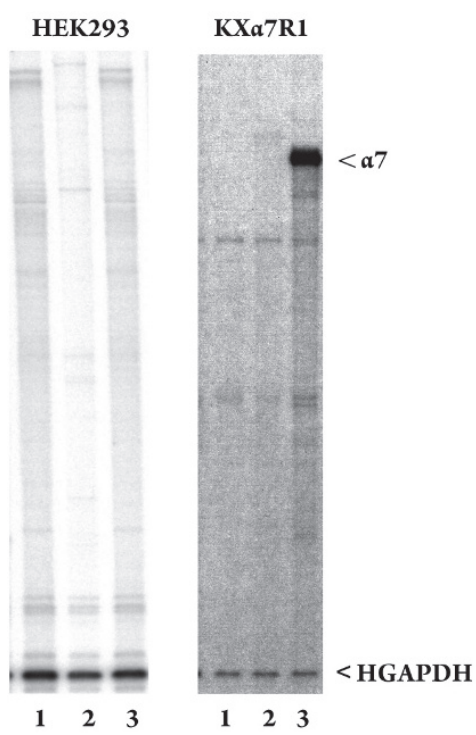

Figure 1. Multiplex RNase protection analysis of expression of $\mathrm{nAChR}$ subunit genes in parent HEK 293 cells and KXa7R1 cells. RNase protection assays were carried out as described in Methods. Total RNA from cells was hybridizedwith a combination of $\left[{ }^{32} \mathrm{P}\right]$ labeled anti-sense probes corresponding to the nine rat $\mathrm{nAChR}$ subunit genes $\alpha 2, \alpha 3$, $\alpha 4$ (lane 1 ); $\alpha 5, \alpha 6, \beta 4$ (lane 2$) ; \alpha 7, \beta 2, \beta 3$ (lane 3 ). The probe corresponding to human GAPDH gene was used as an internal and loading control (all lanes). The images of expression profiles of HEK 293 and KXa7R1 cell lines were from different experiments but all mRNA measurements were repeated at least 3 times with similar results.

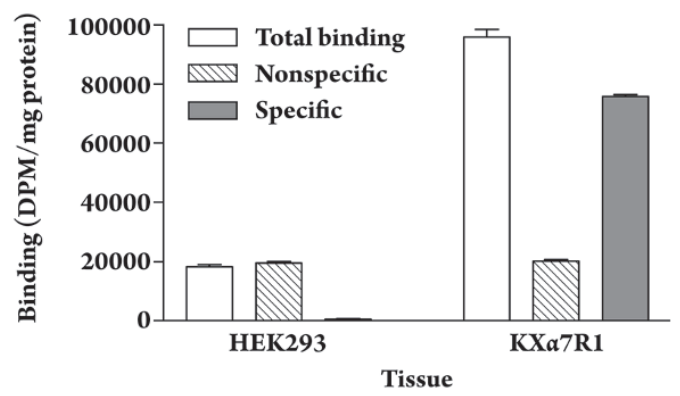

Figure 2. Binding of $\left[{ }^{125} \mathrm{I}\right]-\alpha-\mathrm{BTX}(2 \mathrm{nmol} / \mathrm{L})$ to membrane homogenates from untransfected HEK293 cells and KXa7R1 cells expressing the rat $\alpha 7$ subunit gene. Total bindings and nonspecific bindings were determined in the absence and presence of $1 \mathrm{mmol} / \mathrm{L}(-)$-nicotine. Specific binding is defined as the difference between total binding and nonspecific binding. Values are the mean $\pm \mathrm{SD}$ of 4 measurements.

$\alpha 4 \beta 2$, and $\alpha 4 \beta 4^{[28]}$. There was no specific binding of $\left[{ }^{125} \mathrm{I}\right]-\alpha-$ BTX in any of these cell lines (data not shown).

Comparison of binding properties of the $a 7$ homomeric nAChRs in $K X a 7 R 1$ and native $\alpha 7^{*}$ nAChRs in rat hippocampus and cerebral cortex Specific binding of $\left[{ }^{125} \mathrm{I}\right]-\alpha-\mathrm{BTX}$ to membrane homogenates of the KX $\alpha 7 \mathrm{R} 1$ cells was saturable and represented more than $70 \%$ of the total binding at concentrations up to about $2 \mathrm{nmol} / \mathrm{L}\left[{ }^{125} \mathrm{I}\right]-\alpha-$ BTX (Figure 3 ). The density of the $\alpha 7$ receptor binding sites in these cells is somewhat higher than in rat hippocampus or cerebral cortex (Figure 3). Though the nAChRs expressed in the cells have a slightly higher $K_{d}$ value(Table 1 ), the differences in the binding affinities among nAChRs from cells and those from the two native tissues are not significant $(P>0.05$ by one-factor analysis of variance and Tukey's mutiple comparison test). The binding site densities ( $B_{\max }$ values) of the cells are similar to hippocampus but higher than cortex.

Table 1. Comparison of saturation binding of $\left[{ }^{125} \mathrm{I}\right]-\alpha-\mathrm{BTX}$ in membrane homogenates from KXa7R1 cells, rat hippocampus and cerebral cortex. Assays in KXa7R1 cells, hippocampus and cerebral cortex were run in parallel. Values shown are mean \pm SEM of 3 to 5 independent experiments. See Figure 3 for description of data analyses and curve fittings.

\begin{tabular}{lcc}
\hline \multicolumn{1}{c}{ Tissue } & $\begin{array}{c}K_{\mathrm{d}} \text { value } \\
(\mathrm{nmol} / \mathrm{L})\end{array}$ & $\begin{array}{c}B_{\max } \text { value } \\
(\mathrm{fmol} / \mathrm{mg} \text { protein })\end{array}$ \\
\hline KXa7R1 cells & $0.38 \pm 0.06$ & $60 \pm 17$ \\
Rat hippocampus & $0.28 \pm 0.03$ & $52 \pm 4$ \\
Rat cerebral cortex & $0.33 \pm 0.05$ & $30 \pm 3$ \\
\hline
\end{tabular}

We next assessed the binding affinities of nicotinic ligands, including agonists and antagonists, in binding competition assays. All 13 compounds examined competed effectively for binding sites labeled by $\left[{ }^{125} \mathrm{I}\right]$ - $\alpha$-BTX (about $1 \mathrm{nmol} / \mathrm{L}$ ) in the KXa7R1 cells and the two native rat brain tissues, but the affinities ( $K_{\mathrm{i}}$ values) among the ligands varied widely (Figure 4 and Table 2). The affinity of $\alpha$-BTX is much higher than that of any other ligand examined in all three tissues. The other 12 ligands can be divided (somewhat arbitrarily) into three groups based on their binding affinity for the $a 7 \mathrm{nAChRs}$ expressed in the transfected cells. First, MLA, a relatively selective competitive antagonist at $\alpha 7$ receptors, and epibatidine, an agonist at all nAChRs examined, displayed affinities in the low $\mathrm{nmol} / \mathrm{L}$ range. Although MLA has much lower affinity than $\alpha$-BTX for $\alpha 7$ receptors, its affinities to these receptors in the three tissues $\left(K_{\mathrm{i}}\right.$ values $\left.=6-22 \mathrm{nmol} / \mathrm{L}\right)$ are much higher than to the binding sites at any of the 6 heteromeric nAChR subtypes previously tested, $\alpha 2 \beta 2, \alpha 2 \beta 4, \alpha 3 \beta 2, \alpha 3 \beta 4, \alpha 4 \beta 2, \alpha 4 \beta 4$, where $K_{\mathrm{i}}$ values of MLA were $>2 \mu \mathrm{mol} / \mathrm{L}^{[28]}$. Conversely, the affinity of epibatidine for $\alpha 7$ receptors is about 50-times lower than those of any heteromeric receptors ${ }^{[28]}$. Second, six compounds, $( \pm)$-anatoxin A, anabaseine, A-85380, GTS-21, $(-)$-nicotine and $(-)$-cytisine, showed intermediate affini- 

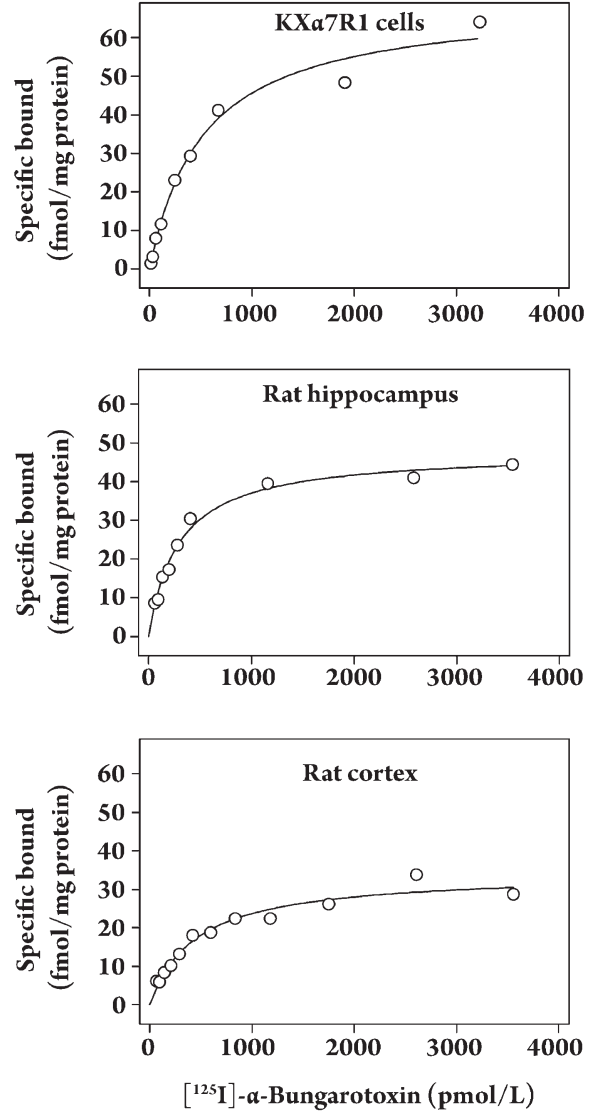

Figure 3. Saturation binding of $\left[{ }^{125} \mathrm{I}\right]-\alpha-\mathrm{BTX}$ to membrane homogenates of KX $\alpha 7 \mathrm{R} 1$ cells, rat hippocampus and cerebral cortex. Saturation binding assays were carried out as described in Methods over a $\left[{ }^{125} \mathrm{I}\right]$ - $\alpha$-BTX concentration range of $0.04-4 \mathrm{nmol} / \mathrm{L}$. Specific binding is defined as the difference between total bindings and nonspecific bindings. Binding data were analyzed using Prism 4 software (GraphPad Software, San Diego, CA). Binding curves shown are representatives of 3 to 5 independent experiments. See Table 1 for a summary of $K_{\mathrm{d}}$ and $B_{\max }$ values from all experiments.

ties with $K_{\mathrm{i}}$ values ranging from $300 \mathrm{nmol} / \mathrm{L}$ to $15 \mu \mathrm{mol} / \mathrm{L}$. Interestingly, (-)-cytisine and (-)-nicotine displayed similar affinities at the $\alpha 7$ receptors in the KX $\alpha 7 \mathrm{R} 1$ cells, but nicotine's affinity was higher than cytisine's at the $\alpha 7$ receptors in the two native tissues. Lastly, acetylcholine, dihydro- $\beta$ erythroidine $(\mathrm{DH} \beta \mathrm{E})$, carbachol and choline, had the lowest affinities, with $K_{\mathrm{i}}$ values $>10 \mu \mathrm{mol} / \mathrm{L}$. The affinities of most of the 13 ligands at $\alpha 7$ receptors in the two native tissues were reasonably similar (Table 2 ) to those in the cell line heterogeneously expressing $\alpha 7 \mathrm{nAChRs}$ (Table 2). However, there were some notable exceptions. For example, MLA, epibatidine, A-85380 and nicotine appear to have 3-9 times lower affinities for the expressed receptors than for the native receptors. Acetylcholine, the endogenous agonist at $\alpha 7$
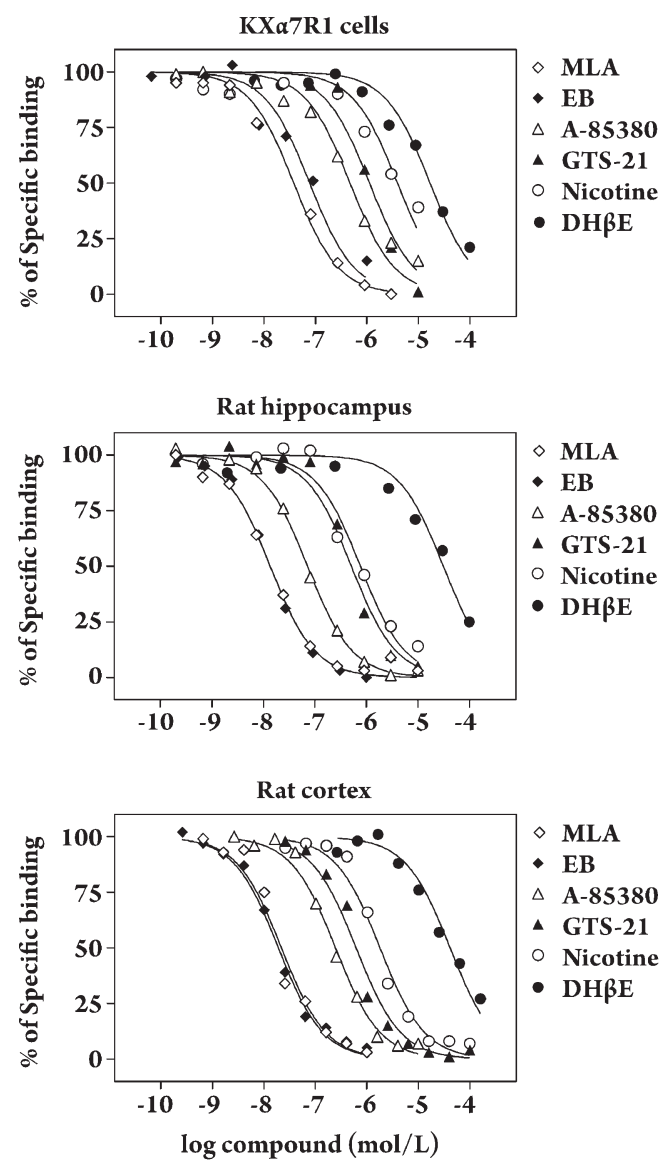

Figure 4. Competition binding of nicotinic ligands for $\left[{ }^{125} \mathrm{I}\right]-\alpha-\mathrm{BTX}$ labeled nAChRs in membrane homogenates of KX $\alpha 7 \mathrm{R} 1$ cells, rat hippocampus and cerebral cortex. Competition binding assays were carried out as described in methods using a $\left[{ }^{125} \mathrm{I}\right]-\alpha$-BTX concentration of about $1 \mathrm{nmol} / \mathrm{L}$. curve fittings were done using prism 4 software (graphpad software, San Diego, CA). binding curves shown are representative of 3 to 6 independent experiments. See Table 2 for a summary of $K_{\mathrm{i}}$ values from all competition experiments for 13 ligands tested.

receptors in native tissues, appeared to have higher affinity for the receptors in the cerebral cortex than in the hippocampus or the cell line.

Channel properties of $\alpha 7 \mathrm{nAChRs}$ expressed in the KXa $7 \mathbf{R 1}$ cells The channel function of the $\alpha 7$ receptors expressed in KX $\alpha 7 \mathrm{R} 1$ cells was assessed using whole-cell current recording. As shown in Figure 5A, application of acetylcholine or nicotine elicited currents in a concentrationdependent manner. Though the potencies of the two agonists in activating channel functions were similar, nicotine $\left(\mathrm{EC}_{50}=180 \pm 40 \mu \mathrm{mol} / \mathrm{L}\right)$ was slightly more potent than acetylcholine $\left(\mathrm{EC}_{50}=280 \pm 19 \mu \mathrm{mol} / \mathrm{L}\right)$. However, the slope of the nicotine curve was shallower than that of acetylcholine, and its maximal current elicited was approximately $75 \%$ of 
A

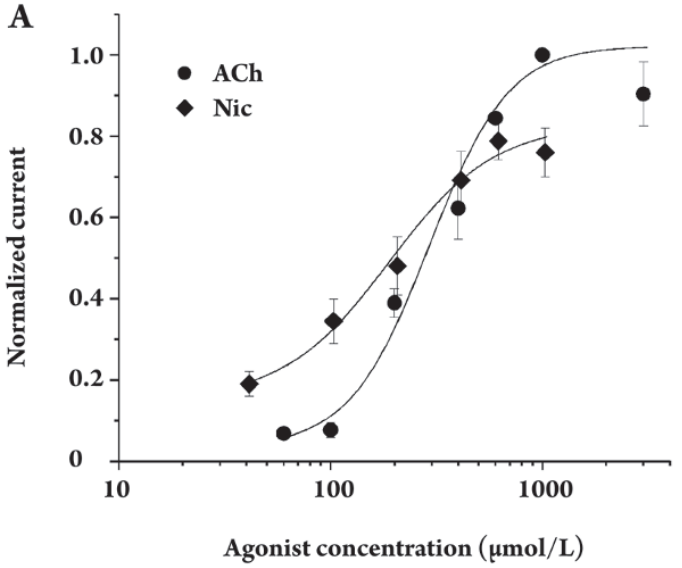

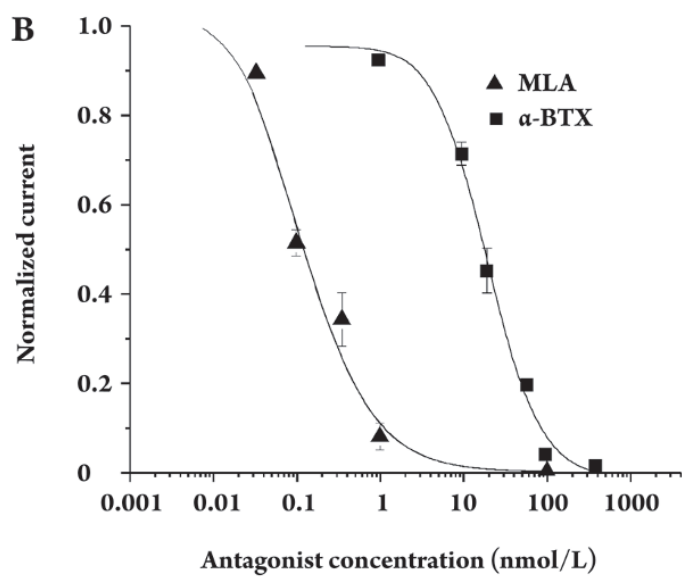

C
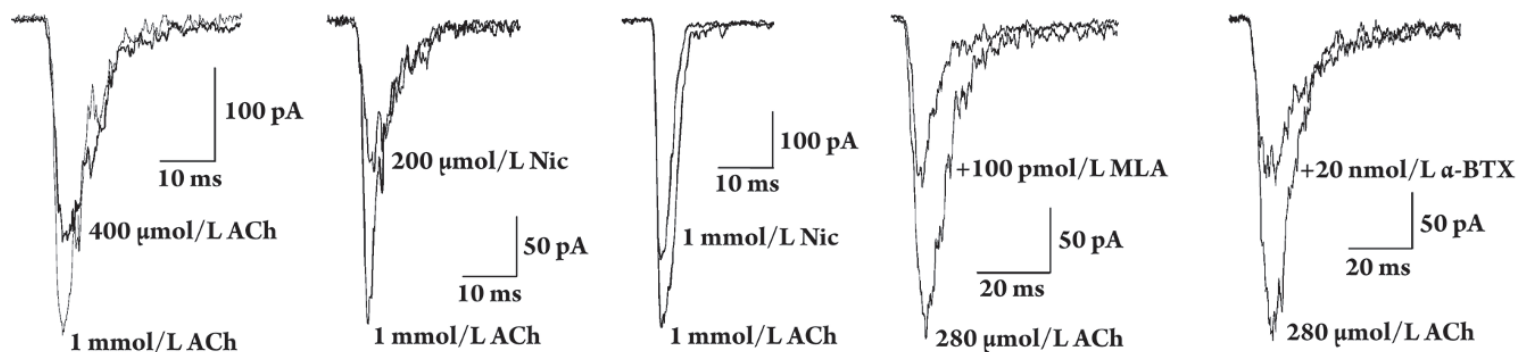

Figure 5. Channel properties of $\alpha 7 \mathrm{nAChRs}$ stably expressed in the KXa7R1 cells. Whole cell patch-clamp recordings were made from KX $\alpha 7 \mathrm{R} 1$ cells at a holding potential of $-80 \mathrm{mV}$. (A) Concentration-dependent activation of channel function by rapidly applied acetylcholine ( ) and $(-)$-nicotine $(\bullet)$. Values represent mean \pm SEM of the peak current amplitudes $(n=3-5)$, normalized to that induced by $1 \mathrm{mmol} / \mathrm{L}$ acetylcholine. (B) Concentration-dependent inhibition of channel function by MLA $(\boldsymbol{\Delta})$ and $\alpha-B T X(\boldsymbol{\square})$. Acetylcholine at $280 \mu \mathrm{mol} / \mathrm{L}$ was used to activate the channel. The peak amplitude of acetylcholine-evoked currents was taken in each cell to normalize the peak amplitude of the currents, evoked in the presence of MLA or $\alpha$-BTX at different concentrations. Values are the mean \pm SEM of the peak current amplitudes $(n=4-5)$. (C) Sample current traces of whole cell current recordings from KXa7R1 cells.

the peak current elicited by acetylcholine at $1 \mathrm{mmol} / \mathrm{L}$ (Figure 5A), indicating that nicotine has an apparent lower efficacy than acetylcholine in activating channel function of the a7 nAChRs. Both of these differences might reflect a greater propensity for nicotine to block the channel at concentrations less than those necessary to fully activate the channel.

To further characterize the channel properties of the receptors, the inhibitory effects of two selective $\alpha 7 \mathrm{nAChR}$ antagonists, $\alpha$-BTX and MLA, were examined when coapplied with $280 \mu \mathrm{mol} / \mathrm{L}$ acetylcholine (the $\mathrm{EC}_{50}$ concentration). Both $\alpha$-BTX and MLA blocked peak amplitudes of acetylcholine-induced currents (Figure 5B). The potency of MLA $\left(\mathrm{IC}_{50}=100 \pm 10 \mathrm{pmol} / \mathrm{L}\right)$ was much higher than that of $\alpha$-BTX $\left(\mathrm{IC}_{50}=19 \pm 2 \mathrm{nmol} / \mathrm{L}\right)$ in blocking channel function of $\alpha 7$ nAChRs. This much greater potency (nearly 200-fold) of MLA than $\alpha$-BTX in blocking $\alpha 7$ receptor function is the reverse of what would have been predicted from the binding affinities of the two antagonists, where $\alpha$-BTX binds with an affinity 270-times greater than MLA.

\section{Discussion}

We have established a stably transfected clonal cell line, KX $\alpha 7 R 1$, that expresses rat $\alpha 7$ nAChRs in HEK-293 cells. The heterologously expressed $\alpha 7 \mathrm{nAChRs}$ bind $\left[{ }^{125} \mathrm{I}\right]-\alpha-\mathrm{BTX}$ with a $K_{\mathrm{d}}$ value of $0.38 \mathrm{nmol} / \mathrm{L}$, which is similar to $K_{\mathrm{d}}$ values of $\alpha 7^{*}$ nAChRs in rat hippocampus and cerebral cortex, 0.28 $\mathrm{nmol} / \mathrm{L}$ and $0.33 \mathrm{nmol} / \mathrm{L}$, respectively (Table 1 ). The $K_{\mathrm{d}}$ value is also similar to the $K_{d}$ value $(0.7 \mathrm{nmol} / \mathrm{L})$ of human a7 nAChRs heterologously expressed in HEK-293 cells ${ }^{[11]}$. We have completed a comprehensive ligand competitive binding study using 13 nicotinic ligands, including the endogenous ligand, acetylcholine, two typical $\alpha 7^{*} \mathrm{nAChR}$ selective ligands, $\alpha$-BTX and MLA, and 10 other natural or 
synthetic nicotinic ligands. The rank order of binding affinities of the $\alpha 7 \mathrm{nAChRs}$ from KXa7R1 cells for these ligands is as the same as that of human $\alpha 7 \mathrm{nAChRs}$ heterologously expressed from HEK-293 ${ }^{[11]}$. To compare binding properties of the rat $\alpha 7 \mathrm{nAChRs}$ in KX $\alpha 7 \mathrm{R} 1$ cells to those of heterologously expressed human $\alpha 7 \mathrm{nAChRs}$ in $\mathrm{K} 28$ cells $^{[11]}$ and in SH-EP1-pCEP4-ha7 cells ${ }^{[34]}$, we did correlation analyses of $K_{\mathrm{i}}$ values of 4 common ligands used for all three cell lines, MLA, (-)-nicotine, (-)-cytisine and carbachol. The values of coefficients of determination $\left(r^{2}\right)$ from all analyses were very high: 0.96 between KXa7R1 cells and SH-EP1-pCEP4ha7 cells; 0.99 between KX $\alpha 7 \mathrm{R} 1$ cells and K28 cells; and 0.96 between SH-EP1-pCEP4-h $\alpha 7$ cells and K28 cells. These analyses indicate that binding properties of heterologously expressed rat and human homomeric $\alpha 7 \mathrm{nAChRs}$ are similar whether expressed in HEK cells or SH-EP-1 cells.

The channel function of the $\alpha 7$ receptor subtype expressed in KXa7R1 cells was assessed using whole-cell current recording. Application of acetylcholine or (-)-nicotine activated a fast, inward-directed current typical of $\alpha 7$ receptors at the holding potential of $-80 \mathrm{mV}$ (Figure 5C). Though potencies of the two agonists in activating channel functions were similar (Figure 5A), nicotine $\left(\mathrm{EC}_{50}=180 \pm 40 \mu \mathrm{mol} / \mathrm{L}\right)$ was slightly more potent than acetylcholine $\left(\mathrm{EC}_{50}=280 \pm 19\right.$ $\mu \mathrm{mol} / \mathrm{L})$. This is consistent with results reported for human a7 nAChRs heterologously expressed in HEK-293 cells ${ }^{[11]}$ or in SH-EP1 cells ${ }^{[38]}$. As expected, the acetylcholine activated current was abolished (Figure 5B) by the two selective $\alpha 7 \mathrm{nAChR}$ antagonists, $\alpha-\mathrm{BTX}$ and MLA. Surprisingly, however, MLA $\left(\mathrm{IC}_{50}=100 \pm 10 \mathrm{pmol} / \mathrm{L}\right)$ was nearly 200 -fold more potent than $\alpha$-BTX $\left(\mathrm{IC}_{50}=19 \pm 2 \mathrm{nmol} / \mathrm{L}\right)$ in blocking $\alpha 7 \mathrm{nAChR}$ channel function. It is conceivable that MLA may not be a "pure competitive antagonist" as widely assumed.

We further compared the binding affinities of ligands at the heterogeneously expressed homomeric nAChRs to those of native $\alpha 7^{*} \mathrm{nAChRs}$ in rat hippocampus and cerebral cortex to determine the degree of similarity between the binding site of the recombinant receptor and the native site. As shown in Figure 4 and Table 2, the ligand binding profile of $\alpha 7 \mathrm{nAChRs}$ in KX $\alpha 7 \mathrm{R} 1$ cells are fairly similar to those in rat hippocampus and cortex. However, the comparison did show several clear differences in ligand binding profiles, especially in the rank orders of affinities. Although it is possible these differences are due to factors not directly related to the structure of the receptors, it is also possible these differences indicate that there are structural differences between the recombinant receptors and native receptors. We speculate that the molecular basis for these differences could be one of the following: i) different transcripts of $\alpha 7$ subunits; ii) dif-
Table 2. Comparison of ligand binding profiles of membrane homogenates from KX $77 \mathrm{R} 1$ cells, rat hippocampus and cortex. Assays in KX $\alpha 7 R 1$ cells, hippocampus and cortex were run in parallel. Values shown are mean \pm SEM of 3 to 6 independent experiments. See Figure 4 for the description of curve fittings.

\begin{tabular}{lccc}
\hline \multicolumn{3}{c}{ Ligand } & \multicolumn{3}{c}{$K_{\mathrm{i}}(\mathrm{nmol} / \mathrm{L})(n)$} \\
& KXa7R1 & Rat hippocampus & Rat cortex \\
\hline a-BTX & $0.077 \pm 0.009$ & $0.28 \pm 0.05$ & $0.77 \pm 0.28$ \\
MLA & $21 \pm 6$ & $7.9 \pm 1.2$ & $6.4 \pm 0.6$ \\
( \pm -Epibatidine & $66 \pm 10$ & $8.1 \pm 0.8$ & $7.5 \pm 0.6$ \\
(+)-Anatoxin-A & $300 \pm 40$ & $590 \pm 210$ & $120 \pm 50$ \\
Anabaseine & $340 \pm 100$ & $770 \pm 210$ & $340 \pm 200$ \\
A-85380 & $420 \pm 50$ & $87 \pm 24$ & $100 \pm 10$ \\
GTS-21 & $760 \pm 220$ & $310 \pm 70$ & $240 \pm 30$ \\
(-)-Nicotine & $3100 \pm 300$ & $420 \pm 80$ & $610 \pm 80$ \\
(-)-Cytisine & $4900 \pm 1700$ & $14000 \pm 4000$ & $2200 \pm 700$ \\
Acetylcholine & $15000 \pm 4000$ & $15000 \pm 3000$ & $2200 \pm 900$ \\
DH $\beta E$ & $15000 \pm 3000$ & $34000 \pm 10000$ & $13000 \pm 1000$ \\
Carbachol & $21000 \pm 7000$ & $47000 \pm 13000$ & $16000 \pm 7000$ \\
Choline & $95000 \pm 45000$ & $170000 \pm 80000$ & $52000 \pm 15000$ \\
\hline
\end{tabular}

ferent posttranslational modifications in $\alpha 7$ subunits, such as formation of disulfide bonds, folding of protein, proteolytic cleavages, glycosylation and/or phosphorylation; iii) alterations of associated proteins; or iv) different subunit composition and subtype abundance. Among these possibilities, the most intriguing is that some native $\alpha 7$ receptors may be heteromeric receptors containing a7 subunits in combination with other neuronal nAChR subunits.

Since successful clonings of neuronal nAChR subunit genes $(\alpha 2-\alpha 8, \beta 2-\beta 4)$ more than 20 years ago, many studies have demonstrated that functional nAChRs could be formed by heterologous expressions of $\alpha 7$ subunit alone $e^{[9-11,35,39]}$ and that there are homomeric $\alpha 7 \mathrm{nAChRs}$ expressed in neuronal systems $^{[40-43]}$. However, over the years, some experimental observations supported the notion that there may be heteromeric receptors containing $\alpha 7$ subunits in combination with other neuronal $\mathrm{nAChR}$ subunits ${ }^{[4-47]}$. A careful examination of subunit compositions of $\alpha 7$ receptors in bovine adrenal chromaffin cells supported the possibility of a small population of heteromeric $\alpha 7$ receptors expressed in chromaffin cells ${ }^{[48]}$. More recently, Liu et al reported the presence of heteromeric $\alpha 7 \beta 2$ receptors in rodent basal forebrain cholinergic neurons ${ }^{[23]}$; moreover, these receptor are more sensitive than are homomeric receptors to functional blockade by oligomeric $A \beta_{1-42}$, which would implicate them in Alzheimer's disease. It will be important to determine if there are heteromeric $\alpha 7^{*}$ receptors in rat hippocampus and cerebral cortex; and if so, how these heteromeric $\alpha 7$ receptors contribute to 
the differences in binding profiles between homomeric $\alpha 7$ nAChRs in KX $\alpha 7 \mathrm{R} 1$ cells and native $\alpha 7^{*}$ nAChRs.

In conclusion, we have established a stably transfected clonal cell line, KX $\alpha 7 \mathrm{R} 1$, which expresses rat $\alpha 7 \mathrm{nAChRs}$ in HEK-293 cells. The $\alpha 7 \mathrm{nAChRs}$ bind to $\left[{ }^{125} \mathrm{I}\right]-\alpha-\mathrm{BTX}$ with sub nanomolar affinity. The receptors are activated by acetylcholine or (-)-nicotine, and the agonist activated currents are blocked by the two selective $\alpha 7 \mathrm{nAChR}$ antagonists, $\alpha$-BTX and MLA. A comprehensive comparative study of ligand binding profiles of the $\alpha 7 \mathrm{nAChRs}$ expressed in this cell line and native $\alpha 7^{*} \mathrm{nAChRs}$ expressed in rat hippocampus and cerebral cortex shows many similarities between the recombinant $\alpha 7 \mathrm{nAChRs}$ and native $\alpha 7$ receptors in rat brain. However, the comparison also shows several clear differences in ligand binding profiles, which suggest the possibility that there are structural differences between the homomeric $\alpha 7 \mathrm{nAChRs}$ expressed in this cell line and those native $\alpha 7^{*}$ receptors in rat hippocampus and cerebral cortex.

\section{Acknowledgements}

This work was supported by National Institutes of Health grants DA06486, DA012976, and DA13199. We thank Niaz SAHIBZADA for his help with whole-cell current measurements.

\section{Author contribution}

Yingxian XIAO designed research; Yingxian XIAO, Galya R ABDRAKHMANOVA, Maryna BAYDYUK and Susan HERNANDEZ performed research; Yingxian XIAO, Galya R ABDRAKHMANOVA and Kenneth J KELLAR analyzed data; Yingxian XIAO, Galya R ABDRAKHMANOVA and Kenneth J KELLAR wrote the paper.

\section{References}

1 Xiao Y, Hernandez SC, Baydyuk M, Kellar KJ. Rat neuronal nicotinic receptors containing alpha7 subunit: pharmacological properties of ligand binding and function. In: Annual Conference of Society for Neuroscience 2003; Washington (DC): Society for Neuroscience; 2003. p 158.3.

2 Whiting PJ, Lindstrom JM. Purification and characterization of a nicotinic acetylcholine receptor from chick brain. Biochemistry 1986; 25: 2082-93.

3 Sargent PB. The diversity of neuronal nicotinic acetylcholine receptors. Ann Rev Neurosci 1993; 16: 403-43.

4 Gotti C, Moretti M, Longhi R, Briscini L, Balestra B, Clementi F. Expression of alpha-bungarotoxin receptor subtypes in chick central nervous system during development. J Receptor Res 1994;14: 335-46.
5 Lindstrom J, Anand R, Peng X, Gerzanich V, Wang F, Li Y. Neuronal nicotinic receptor subtypes. Ann N Y Acad Sci 1995; 757: 100-16.

6 Role LW, Berg DK. Nicotinic receptors in the development and modulation of CNS synapses. Neuron 1996; 16: 1077-85.

7 Lindstrom J. Nicotinic acetylcholine receptors in health and disease. Mol Neurobiol 1997; 15: 193-222.

8 Conroy WG, Berg DK. Nicotinic receptor subtypes in the developing chick brain: appearance of a species containing the alpha4, beta2, and alpha5 gene products. Mol Pharmacol 1998; 53: 392-401.

9 Couturier S, Bertrand D, Matter JM, Hernandez MC, Bertrand $\mathrm{S}$, Millar N, et al. A neuronal nicotinic acetylcholine receptor subunit (alpha 7) is developmentally regulated and forms a homooligomeric channel blocked by alpha-BTX. Neuron 1990; 5: 847-56.

10 Seguela P, Wadiche J, Dineley-Miller K, Dani JA, Patrick JW. Molecular cloning, functional properties, and distribution of rat brain alpha 7: a nicotinic cation channel highly permeable to calcium. J Neurosci 1993; 13: 596-604.

11 Gopalakrishnan M, Buisson B, Touma E, Giordano T, Campbell JE, Hu IC, et al. Stable expression and pharmacological properties of the human alpha 7 nicotinic acetylcholine receptor. Eur J Pharmacol 1995; 290: 237-46.

12 Fuchs PA, Murrow BW. A novel cholinergic receptor mediates inhibition of chick cochlear hair cells. Proceedings 1992; 248: 35-40.

13 Vijayaraghavan S, Pugh PC, Zhang ZW, Rathouz MM, Berg DK. Nicotinic receptors that bind alpha-bungarotoxin on neurons raise intracellular free $\mathrm{Ca}^{2+}$. Neuron 1992; 8: 353-62.

14 Bertrand D, Galzi JL, Devillers-Thiery A, Bertrand S, Changeux JP. Mutations at two distinct sites within the channel domain M2 alter calcium permeability of neuronal alpha 7 nicotinic receptor. Proc Natl Acad Sci USA 1993;90: 6971-5.

15 McGehee DS, Heath MJ, Gelber S, Devay P, Role LW. Nicotine enhancement of fast excitatory synaptic transmission in CNS by presynaptic receptors. Science 1995; 269: 1692-6.

16 Gray R, Rajan AS, Radcliffe KA, Yakehiro M, Dani JA. Hippocampal synaptic transmission enhanced by low concentrations of nicotine. Nature 1996; 383: 713-6.

17 Albuquerque EX, Alkondon M, Pereira EF, Castro NG, Schrattenholz A, Barbosa CT, et al. Properties of neuronal nicotinic acetylcholine receptors: pharmacological characterization and modulation of synaptic function. J Pharmacol Exp Ther 1997; 280: $1117-36$.

18 Colquhoun LM, Patrick JW. Pharmacology of neuronal nicotinic acetylcholine receptor subtypes. Advances Pharmacol 1997; 39: 191-220.

19 Levin ED, Bettegowda C, Blosser J, Gordon J. AR-R17779, and alpha7 nicotinic agonist, improves learning and memory in rats. Behav Pharmacol 1999;10: 675-80.

20 Levin ED, Christopher NC, Weaver T, Moore J, Brucato F. Ventral hippocampal ibotenic acid lesions block chronic nicotine-induced spatial working memory improvement in rats. Brain Res Cogn Brain Res 1999; 7: 405-10.

21 Wang HY, Lee DH, Davis CB, Shank RP. Amyloid peptide Abeta (1-42) binds selectively and with picomolar affinity to alpha7 nicotinic acetylcholine receptors. J Neurochem 2000; 75: 
$1155-61$.

22 Liu Q, Kawai H, Berg DK. beta -Amyloid peptide blocks the response of alpha 7-containing nicotinic receptors on hippocampal neurons. Proc Natl Acad Sci USA 2001; 98: 4734-9.

23 Liu Q, Huang Y, Xue F, Simard A, DeChon J, Li G, et al. A novel nicotinic acetylcholine receptor subtype in basal forebrain cholinergic neurons with high sensitivity to amyloid peptides. J Neurosci 2009; 29: 918-29.

24 Wang H, Yu M, Ochani M,Amella CA, Tanovic M, Susarla S, et al. Nicotinic acetylcholine receptor alpha7 subunit is an essential regulator of inflammation. Nature 2003; 421: 384-8.

25 Kem WR. The brain alpha7 nicotinic receptor may be an important therapeutic target for the treatment of Alzheimer's disease: studies with DMXBA (GTS-21). Behav Brain Res 2000; 113: 169-81.

26 Arneric SP, Holladay M, Williams M. Neuronal nicotinic receptors: a perspective on two decades of drug discovery research. Biochem Pharmacol 2007; 74: 1092-101.

27 Xiao Y, Meyer EL, Thompson JM, Surin A, Wroblewski J, Kellar KJ. Rat alpha3/beta4 subtype of neuronal nicotinic acetylcholine receptor stably expressed in a transfected cell line: pharmacology of ligand binding and function. Mol Pharmacol 1998; 54: 322-33.

28 Xiao Y, Kellar KJ. The comparative pharmacology and up-regulation of rat neuronal nicotinic receptor subtype binding sites stably expressed in transfected mammalian cells. J Pharmacol Exp Ther 2004; 310: 98-107.

29 Eaton JB, Peng JH, Schroeder KM, George AA, Fryer JD, Krishnan $C$, et al. Characterization of human alpha 4 beta 2 -nicotinic acetylcholine receptors stably and heterologously expressed in native nicotinic receptor-null SH-EP1 human epithelial cells. Mol Pharmacol 2003; 64: 1283-94.

30 Lewis TM, Harkness PC, Sivilotti LG, Colquhoun D, Millar NS. The ion channel properties of a rat recombinant neuronal nicotinic receptor are dependent on the host cell type. J Physiol 1997; 505: 299-306.

31 Stauderman KA, Mahaffy LS, Akong M, Veliçelebi G, ChavezNoriega LE, Crona JH, et al. Characterization of human recombinant neuronal nicotinic acetylcholine receptor subunit combinations alpha2beta4, alpha3beta4 and alpha4beta4 stably expressed in HEK293 cells. J Pharmacol Exp Ther 1998; 284: 777-89.

32 Whiting P, Schoepfer R, Lindstrom J, Priestley T. Structural and pharmacological characterization of the major brain nicotinic acetylcholine receptor subtype stably expressed in mouse fibroblasts. Mol Pharmacol 1991; 40: 463-72.

33 Puchacz E, Buisson B, Bertrand D, Lukas RJ. Functional expression of nicotinic acetylcholine receptors containing rat alpha 7 subunits in human SH-SY5Y neuroblastoma cells. FEBS Lett 1994; 354: 155-9.

34 Peng JH, Fryer JD, Hurst RS, Schroeder KM, George AA, Morrissy $S$, et al. High-affinity epibatidine binding of functional, human alpha7-nicotinic acetylcholine receptors stably and heterologously expressed de novo in human SH-EP1 cells. J Pharmacol Exp Ther
2005; 313: 24-35.

35 Peng JH, Lucero L, Fryer J, Herl J, Leonard SS, Lukas RJ. Inducible, heterologous expression of human alpha7-nicotinic acetylcholine receptors in a native nicotinic receptor-null human clonal line. Brain Res 1999; 825: 172-9.

36 Quik M, Choremis J, Komourian J, Lukas RJ, Puchacz E. Similarity between rat brain nicotinic alpha-bungarotoxin receptors and stably expressed alpha-bungarotoxin binding sites. J Neurochem 1996; 67: 145-54.

37 Virginio C, Giacometti A, Aldegheri L, Rimland JM, Terstappen GC. Pharmacological properties of rat alpha 7 nicotinic receptors expressed in native and recombinant cell systems. Eur J Pharmacol 2002; 445: 153-61.

38 Zhao L, Kuo YP, George AA, Peng JH, Purandare MS, Schroeder KM, et al. Functional properties of homomeric, human alpha 7-nicotinic acetylcholine receptors heterologously expressed in the SH-EP1 human epithelial cell line. J Pharmacol Exp Ther 2003; 305: 1132-41.

39 Peng X, Katz M, Gerzanich V, Anand R, Lindstrom J. Human alpha 7 acetylcholine receptor: cloning of the alpha 7 subunit from the SH-SY5Y cell line and determination of pharmacological properties of native receptors and functional alpha 7 homomers expressed in Xenopus oocytes. Mol Pharmacol 1994; 45: 546-54.

40 Bertrand D, Bertrand S, Ballivet M. Pharmacological properties of the homomeric alpha 7 receptor. Neurosci Lett 1992; 146: 87-90.

41 Chen D, Patrick JW. The alpha-bungarotoxin-binding nicotinic acetylcholine receptor from rat brain contains only the alpha7 subunit. J Biol Chem 1997; 272: 24024-9.

42 Drisdel RC, Green WN. Neuronal alpha-bungarotoxin receptors are alpha7 subunit homomers. J Neurosci 2000; 20: 133-9.

43 Albuquerque EX, Pereira EF, Castro NG, Alkondon M, Reinhardt $\mathrm{S}$, Schröder $\mathrm{H}$, et al. Nicotinic receptor function in the mammalian central nervous system. Ann N Y Acad Sci 1995; 757: 48-72.

44 Gotti C, Ogando AE, Hanke W, Schlue R, Moretti M, Clementi F. Purification and characterization of an alpha-bungarotoxin receptor that forms a functional nicotinic channel. Proc Natl Acad Sci USA 1991; 88: 3258-62.

45 Cuevas J, Berg DK. Mammalian nicotinic receptors with alpha7 subunits that slowly desensitize and rapidly recover from alphabungarotoxin blockade. J Neurosci 1998; 18: 10335-44.

$46 \mathrm{Yu}$ CR, Role LW. Functional contribution of the alpha7 subunit to multiple subtypes of nicotinic receptors in embryonic chick sympathetic neurones. J Physiol 1998; 509: 651-65.

47 Khiroug SS, Harkness PC, Lamb PW, Sudweeks SN, Khiroug L, Millar NS, et al. Rat nicotinic ACh receptor alpha7 and beta2 subunits co-assemble to form functional heteromeric nicotinic receptor channels. J Physiol 2002; 540: 425-34.

48 El-Hajj RA, McKay SB, McKay DB. Pharmacological and immunological identification of native alpha7 nicotinic receptors: evidence for homomeric and heteromeric alpha7 receptors. Life Sci 2007; 81: 1317-22. 